OPEN ACCESS

Edited by:

Dagmar Haase,

Humboldt University of

Berlin, Germany

Reviewed by:

Mekuria Argaw Denboba,

Addis Ababa University, Ethiopia

Tibebu Assefa,

Addis Ababa University, Ethiopia

*Correspondence:

Judit Boros

boros_judit@phd.ceu.edu

Specialty section:

This article was submitted to

Urban Greening,

a section of the journal

Frontiers in Sustainable Cities

Received: 30 November 2020

Accepted: 05 May 2021

Published: 02 June 2021

Citation:

Boros J and Mahmoud I (2021) Urban Design and the Role of Placemaking in Mainstreaming Nature-Based

Solutions. Learning From the

Biblioteca Degli Alberi Case Study in

Milan. Front. Sustain. Cities 3:635610.

doi: $10.3389 /$ frsc. 2021.635610

\section{Urban Design and the Role of Placemaking in Mainstreaming Nature-Based Solutions. Learning From the Biblioteca Degli Alberi Case Study in Milan}

\author{
Judit Boros $^{1 *}$ and Israa Mahmoud ${ }^{2}$ \\ ${ }^{1}$ Department of Environmental Sciences and Policy, Central European University, Vienna, Austria, ${ }^{2}$ Laboratorio di \\ Simulazione Urbana, Department of Architecture and Urban Studies (DASTU), Politecnico di Milano, Milan, Italy
}

Nature-based solutions' (NBS) relevance for tackling environmental challenges has been on the frontiers of urban regeneration mechanisms since the beginning of the 2010s. There is an increasing interest in applying NBS in urban planning and design to build support and engagement for sustainable urban development. However, NBS's operational use as deliberate design interventions is not widely reflected in the scientific discourse, more evidence is needed on how functional and viable aspects of urban nature can be conceptualized in urban design. This calls to explore the ways urban design can advance their understanding as part of place-specific, designed urban spaces. Through an ex-post analysis, the authors examined the design and implementation process of an exemplary NBS project, the Biblioteca degli Alberi park in Milan, part of one of the largest, recent urban regeneration projects in Europe. In a synthetic analysis, design drivers, enablers, and deficiencies are discussed, which affect the park's performance both from human-centered and nature-based perspectives. The park's case demonstrates design actions and considerations affecting all stages of the life-cycle of an NBS, from the creative design phase to the development, use, and management phases, and how urban design can create conditions for amplifying the multifunctional potential of urban ecosystems. The results highlight the importance of integrating an urban ecology perspective in the entirety of the design process when implementing NBS, consequently for a successful re-scoping of urban design and planning practices to infuse human-centeredness with "nature-basedness."

Keywords: urban design, nature-based solutions, placemaking, urban regeneration, urban parks

\section{INTRODUCTION}

The term nature-based solutions (NBS) is used as an umbrella concept for applying natural systems to intentionally tackle contemporary environmental challenges (Bulkeley et al., 2017; Nesshöver et al., 2017; Raymond et al., 2017). A connected system of NBS- such as greenways or large urban parks- can sustain healthy urban environments, mitigate the effects of intense urbanization, and can be applied innovatively to issues such as water management (urban drainage, water retention, 
excess water), climate change (heat waves, heat islands), and health and well-being (air quality, recreation) (Kabisch et al., 2016). They are simultaneously providing multiple social, economic, and environmental co-benefits (European Commission, 2015), associated with sustainable urban development (McCormick et al., 2013; Bayulken and Huisingh, 2015; Connop et al., 2015) and regenerative development (Xiang et al., 2017).

Recent studies have engaged with the urban policy, planning, and governance implications of NBS (Frantzeskaki, 2019; Mahmoud and Morello, 2021; Bush and Doyon 2019). There is an increasing interest by urban planners and policymakers in defining and measuring knowledge on the evidence on NBS' potential to address these challenges (Brink et al., 2016). Their multi-functional aspect is one of their core strengths, and one of their most significant obstacles at the same time (Hansen et al., 2019). Translating the abstract frameworks and assessments of how NBS work into execution and implementation needs to be approachable for investors, companies, the public sector, and communities. Understanding the regenerative potential of NBS, with benefits outweighing costs, is fundamental to the implementation of NBS (Mell et al., 2013) —as awareness by decision-makers and a sense of urgency play an essential role in the growing advocacy for NBS (van der Jagt et al., 2020). Quality urban design and form are an essential engine of change to foster urban regeneration $(\mathrm{CABE}, 2001)$ and provide powerful tools to overcome uncertainty regarding the engagement and adoption of NBS.

Several scholars address the role and importance of designing urban spaces to build support and engagement for sustainable urban development and to improve human-nature relationships (Gulsrud et al., 2018). Urban design's role is to provide integrative solutions that strengthen urban environments from economic, social and environmental aspects and guide the intervention as a strategy (Palazzo and Steiner, 2011). This understanding extends the traditional urban design interests of place-making or livability to build on different theoretical domains to deal with the technological, ecological, cultural, and social interconnections and bring them forward in design and innovation decisions for the long-term visions of society (Ceschin and Gaziulusoy, 2016). However, the means of reorienting urban design toward the strategic use of natural elements-that is, the operational use of NBS as deliberate design interventions-are not widely reflected in either research or practice. This calls for exploring NBS as major design components in the spatial environment related to the human dimension that stimulates senses and perception and ultimately influences well-being.

In this paper, we seek to demonstrate how urban design attempts and processes influence the outcomes of NBS in the urban environment and, by understanding the complete design process, how can the provision of various services by urban ecosystems be enhanced. To do this, we analyze NBS as part of place-specific, designed urban spaces to highlight how urban communities benefit including how human and non-human values are considered during urban design processes, in other words, how the design influences the outcomes of NBS.
We conducted a case study research to demonstrate that the design, configuration, and use of urban public spaces can create conditions for a nature-based design to emerge and develop even within primarily human-centered conditions. The study's subject is the design process of an NBS, the Biblioteca degli Alberi di Milano park (hereinafter referred to as BAM), part of a largescale regeneration scheme in the center of Milan, the Porta Nuova area. The case selection was based on the complexity and significance of the site, portraying an outcome of public-private relationships between landowners, developers, and users and shows an investment grounded in the strategic design of urban spaces, producing enduring use values in social, environmental, and economic terms.

\section{MATERIALS AND METHODS \\ Theoretical Framework and Research Approach}

This paper's research approach builds on different bodies of literature to utilize a framework fitting to fully examine the urban design of nature-based places. The literature on placemaking provides appropriate tools to depict different levels of engagement with NBS. Examining the urban design outcomes with a place-based lens can offer an understanding of how human-centered qualities are conceptualized and delivered and communicates the intangible and experiential qualities that contribute to making thriving places and successful designs. The placemaking lens is complemented with an ecological lens to assess the place qualities for the non-human alike, as implicit outcomes of the design efforts. Finally, the outcomes are compared to the different process stages that constitute the full urban design process. Figure 1 illustrates the research approach, expanded in detail through the next paragraphs.

Placemaking is an inherently people-centered approach to the planning, designing and management of public spaces in cities, as it emphasizes the relationships between individuals, communities, and urban spaces (Wyckoff, 2014). It actualizes these by enabling and empowering people to create attractive, sociable, healthy, and green streets and places. The approach primarily focuses on meeting basic human needs, on people's experience within a space, and transforming it into a "place." Defined by the Project for Public Spaces (2016), these key qualities are: Sociability - a place for various interactions, Uses \& Activities - a place where people can engage in meaningful activities, Comfort \& Image-a place for easy and comfortable use, and Access \& Linkages-a place accessible to all. These qualities are regarded as essential for the physical, mental, and social well-being of people, and concurrently form the basis for the economic reasoning of placemaking (Markusen and Nicodemus, 2014; Cohen et al., 2018; Carmona, 2019). From an ecological perspective, placemaking has been studied in the context of climate change adaptation (Nouri and Costa, 2017) and as green placemaking (Gulsrud et al., 2018).

However, placemaking often lacks an ecological approach and has limited long-term benefits, staying at a superficial beautification or place-masking level (Fincher et al., 2016). 


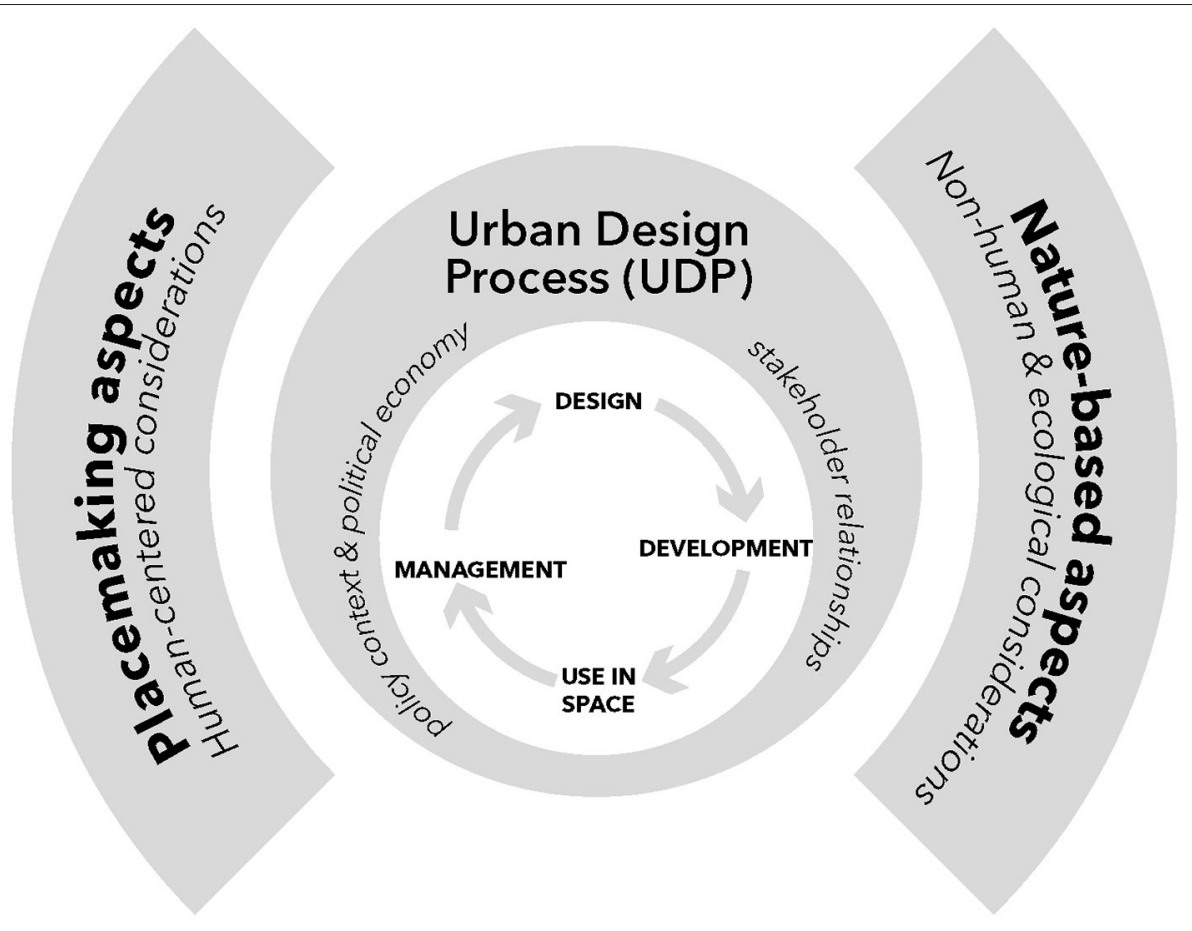

FIGURE 1 | Urban design process dimensions viewed from the lens of placemaking and nature-based solutions. Adapted from Carmona 2014.

Hes et al. (2020) argue that although the connection with nature is evidently strongly related to well-being, the traditional conceptualization of placemaking ignores non-human elements and ecological systems as equal parts, or users of space. Consequently, placemaking practice needs to recognize the value of ecological systems in their own right and embrace the interconnectedness between these dimensions by an integrated re-conceptualization of the long-term desired benefits that include the "input-output-outcome-legacy aspects." We apply Hes et al's (2020) "lens" to integrate it into the research framework, to include the social and ecological performance of place, its qualities for humans and non-human alike.

The "input-output-outcome-legacy aspects" are similarly formulated to what Carmona (2014) defined as the integrated framework of the urban design process (hereinafter called the UDP framework), to "compare outcomes with processes of delivery (Carmona, 2014, p. 4).” The UDP framework presents a helpful structure to assess the quality of design in the built environment; incorporating the "processes" and "outcomes" of development, regeneration and the long-term management of places-in other words "the complete placeshaping process" over time. According to Carmona (2014), the "process" factors explain how places are shaped, together with the historical and contemporary "context" for public space generation and regeneration. While, undoubtedly, urban design operates in different spatial scale complexities and varieties, urban spaces are naturally part of larger urban design schemes, development plans, policy approaches, and are in interaction with mechanisms of long-term urban adaptation and change. Thus, focusing on a single urban space can also help reveal the intricate effects of larger urban processes.

The UDP framework is applied in this paper as a starting point to assess the "processes" and "outcomes" of an NBS design project, to show how urban design can help enhance interlinkages between the human and non-human elements of the urban ecosystem. The contextual factors; the history and traditions of place and the contemporary policy context, and power relationships between stakeholders are covered in the first part of the Results section, followed by the description of "outcomes," and the recollection of the "design process" stages through which the NBS was created: (1) design, (2) development, (3) space in use, and (4) management.

\section{Data Collection and Analysis}

A qualitative single-case study approach is used in a revelatory manner (Yin, 2017), based on the analysis of primary and secondary data to derive lessons on the contributions of urban design within the broader NBS planning context. A layered approach is applied to the inquiry, demonstrated in other studies of urban greening (seen in, for example Gulsrud et al., 2018; Buijs et al., 2019; Coffey et al., 2020). Thus, the case study is built by reporting the socio-cultural placemaking and the NBS perspectives as outcomes of the design process and assessing both within the broader UDP context and design dimensions, as shown in Figure 1.

The findings are based on data from multiple sources: (1) nine semi-structured interviews, (2) documents connected to 
TABLE 1 | Key informants, experts (interview dates: between 04 and 05. 2019).

\begin{tabular}{lll}
\hline Informant & Expertise and organization & Type of contact \\
\hline \#M01 & Urbanist and researcher, Stefano Boeri & In person \\
& Architects & \\
\#M02 & Architect and project leader, Stefano Boeri & In person \\
& Architects & \\
\#M03 & Project manager, Ambiente Italia & In person \\
\#M04 & Researcher, Ambiente Italia & In person \\
\#M05 & Architect, ROOFmatters & In person \\
\#M06 & Marketing manager, COIMA and & In person \\
& Fondazione Riccardo Catella & Telephone \\
\#M07 & Civic activist, Federazione dei Verdi & In person \\
\#M08 & Independent designer & In person \\
\#M09 & Architect, LAND & In person \\
\#M10 & Architect and project manager, LAND & Email \\
\#M11 & Architect and managing director, Carlo & \\
& Ratti Associati &
\end{tabular}

Number of persons/organizations contacted: 26.

Persons interviewed: 11 (9 semi-structured, in person).

Average length of the in-person interviews: $52 \mathrm{~min}$.

the development of BAM and the urban regeneration area, (3) site visits for direct observations and, (4) participation in three organized guided tours in Porta Nuova featuring BAM during springtime in 2019. The qualitative, semi-structured interviews were conducted in Milan between March and April 2019, with key informants who are considered local experts with an intrinsic knowledge and expertise of Milanese urban planning and design (Table 1). The interviewees were employees of key project stakeholders involved in developing BAM and the Porta Nuova regeneration process. Architects, project leaders and researchers of participating architect firms, and representatives of the developer company were interviewed. Additionally, civic activists and NGO employees operating in the environmental policy realm were interviewed, which provided supplementary contextual insight into the transformation of the Porta Nuova area. The selection of interview partners was made in several steps. First, orientation discussions (not counted in the interview list) were conducted to find possible contacts with the help of the Rinverdiamo Milano ("Let's re-green Milan") Action Lab of CLEVER Cities ${ }^{1}$, where urban greening professionals from NGOs, Academia, and the Municipality of Milan were present (Mahmoud and Morello, 2020). They provided additional contacts who, through snowball sampling, led us to the persons with expert knowledge and important positions whom we could purposefully address to gain primary data on the park's design and the area's development process. The semi-structured interviews were guided by questions that allowed for understanding the participants' backgrounds, role in the process, or their relationship to BAM and the area. They were structured to investigate both the contextual aspects and factual proceedings of BAM's UDP.

${ }^{1}$ https://clevercities.eu/.
A set of secondary data was gathered through a desk study of policy and strategy documents, reached online, or received via interviewees. Policy documents with binding value were collected and examined, relating to Milan's territorial governance and goals to achieve urban green transformation and resilience through urban planning and design. The area master plans, the conceptual design, and BAM's technical plans supported our reconstruction of insights on the instrumental descriptions of the designed place. Simultaneously, press materials and reports by investors and developers revealed the development's inherent details. Furthermore, newspaper articles were reviewed to learn about the citizens' and critics' opinions on BAM and the Porta Nuova development.

The site visits and guided tours provided opportunities for additional qualitative techniques in the data collection, to register details and nuances of people's interaction with the projects, following the "public life research" traditions of Gehl and Svarre (2013). The site visits consisted of $15 \mathrm{~h}$ of nonparticipant observations over six occasions, between March and April 2019. The observations were systematic to capture users' likes and dislikes throughout the analysis, although no specific dislikes were noted. These techniques allowed us to combine a "place-responsive" methodology to the research (Carmona, 2010), which helped to further saturate the findings through informal, incidental conversations with users of the space, tours' participants (both tourists and locals) and their organizers.

During data collection, an interpretive stance was taken to ensure additional insights emerge consistently with the exploratory nature of the case study. All interview content was recorded and later transcribed as the primary source of evidence for the case, then combined with the researchers' observations, notes, and field diary together with the strategic and policy documents, plans, and additional materials to ensure data triangulation. After combining the diverse qualitative findings, the data was coded, organized in tables and analyzed based on the elements of the UDP framework (see Table 2), first in a descriptive manner to identify how the place was formed in depth. Second, data was analyzed to evaluate the process through the lenses of placemaking and nature-based characteristics. In the final step of the analysis, we integrated the results of the two previous exercises to identify the emerging nature-based placemaking narratives around Biblioteca degli Alberi in relation to the UDP framework, and to address the initial propositions of the study.

\section{RESULTS: ANALYZING THE URBAN DESIGN PROCESS FOR NATURE-BASED PLACEMAKING}

\section{Context: Milan and the Regeneration of Porta Nuova}

Milan is the unofficial "Italian economic capital," situated in Lombardy, the most populous region, inhabited by about 10 million people. The 1950s' heavy industrialization made Milan the "capital miracle" (Foot, 2001) although causing major environmental challenges for the city and its area. By the 
TABLE 2 | Indicators and description of UDP sub-processes (Carmona, 2014).

\begin{tabular}{|c|c|c|c|c|c|}
\hline & Indicators & Description & & Indicators & Description \\
\hline \multirow[t]{5}{*}{$\begin{array}{l}\text { Shaping } \\
\text { through } \\
\text { design }\end{array}$} & Establishing a vision & $\begin{array}{l}\text { Generation an agreed } \\
\text { 'vision' for positive change. }\end{array}$ & $\begin{array}{l}\text { Shaping } \\
\text { through development }\end{array}$ & $\begin{array}{l}\text { Lead and } \\
\text { coordinate }\end{array}$ & $\begin{array}{l}\text { Coordination of interests } \\
\text { between the array of } \\
\text { stakeholder. Critical role of } \\
\text { project champions. }\end{array}$ \\
\hline & Making trade-offs & $\begin{array}{l}\text { Balanced coordination } \\
\text { between assigned } \\
\text { authorities during design } \\
\text { process. }\end{array}$ & & $\begin{array}{l}\text { Marshaling } \\
\text { resources }\end{array}$ & $\begin{array}{l}\text { Coordination of } \\
\text { funding sources. }\end{array}$ \\
\hline & Innovating (or not) & $\begin{array}{l}\text { Creating innovation in uses } \\
\text { of the space. }\end{array}$ & & $\begin{array}{l}\text { Negotiating } \\
\text { consents }\end{array}$ & $\begin{array}{l}\text { Negotiating the non-market } \\
\text { space-defining mechanisms } \\
\text { and regulatory instruments. }\end{array}$ \\
\hline & Creating value & $\begin{array}{l}\text { Reaching for maximum } \\
\text { 'use' value in the social, } \\
\text { economic and ecologic } \\
\text { spheres. }\end{array}$ & & Injecting quality & $\begin{array}{l}\text { Influencing final outcomes of } \\
\text { the space potential. }\end{array}$ \\
\hline & Shaping constraints & $\begin{array}{l}\text { The influence of the } \\
\text { regulatory constraints on } \\
\text { the overall outcomes. }\end{array}$ & & Garnering support & $\begin{array}{l}\text { Various ways of } \\
\text { community involvement. }\end{array}$ \\
\hline \multirow[t]{5}{*}{$\begin{array}{l}\text { Shaping } \\
\text { through use }\end{array}$} & Activities & $\begin{array}{l}\text { Creating activities, patterns } \\
\text { of use. }\end{array}$ & $\begin{array}{l}\text { Shaping } \\
\text { through management }\end{array}$ & $\begin{array}{l}\text { Investing } \\
\text { long-term }\end{array}$ & $\begin{array}{l}\text { Involve expertise for } \\
\text { establishing long-term } \\
\text { stewardship and ongoing } \\
\text { funding. }\end{array}$ \\
\hline & Associations & $\begin{array}{l}\text { Introducing levels of } \\
\text { services meeting needs of } \\
\text { different users. }\end{array}$ & & $\begin{array}{l}\text { Everyday } \\
\text { stewardship }\end{array}$ & $\begin{array}{l}\text { Operating appropriate } \\
\text { management system for } \\
\text { building in resilience. }\end{array}$ \\
\hline & Amenities & $\begin{array}{l}\text { Providing for the } \\
\text { convenience of users. }\end{array}$ & & Curating place & $\begin{array}{l}\text { Embracing a proactive } \\
\text { approach for organized } \\
\text { activities, for a stimulating } \\
\text { environment. }\end{array}$ \\
\hline & Adaptation & $\begin{array}{l}\text { Enabling adaptation with } \\
\text { new uses in the space. }\end{array}$ & & Controlling space & $\begin{array}{l}\text { Operating appropriate } \\
\text { control in the space. }\end{array}$ \\
\hline & Appropriation & $\begin{array}{l}\text { Reflecting appropriateness } \\
\text { for different uses and users } \\
\text { in the space. }\end{array}$ & & $\begin{array}{l}\text { Redevelop / } \\
\text { revitalize }\end{array}$ & $\begin{array}{l}\text { Awareness of the continual } \\
\text { place-shaping processes. }\end{array}$ \\
\hline
\end{tabular}

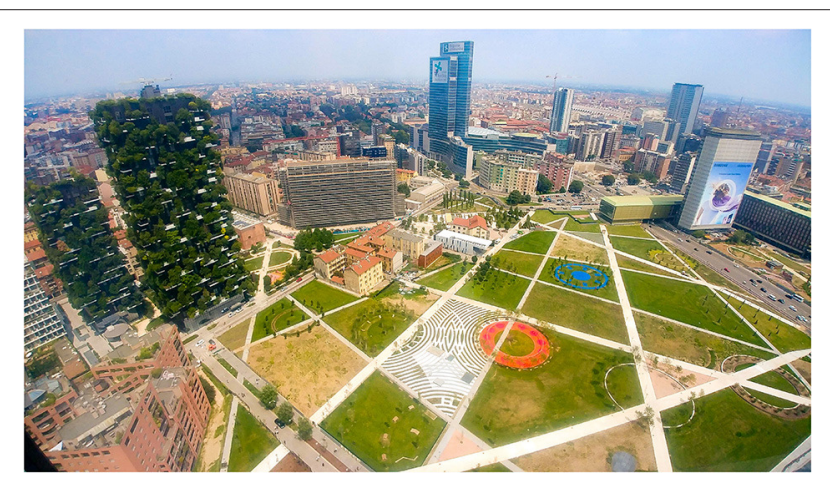

FIGURE 2 | Aerial view of BAM showing the spatial structure of the park and between the pathways, June 2018. Source: Luca Volpi, 2018; user Goldmund100 on Wikimedia (CC BY-SA 4.0).

1990s, the shift from an industrial to a service-based economy has turned large territories abandoned and deteriorating and left the city with an enormous amount of industrial waste and unused railroad tracks on a territory summing up to 600 hectares (Galbraith, 2007). Additionally, the city suffers from traffic and noise pollution, climate challenges such as heat waves in summer and acute flooding in winter, while air quality problems intensified to an extreme level that made the city (the Milan area, together with Turin and Brescia) the second most smoggy city in Europe in 2008 (ISTAT, 2010), and the situation has not changed much by 2016 (European Environment Agency, 2019). To address these issues, the latest changes to Milan's territorial plan for 2030 set urban greening as one of its top priorities. Transforming industrial wastelands and reviving unused areas into healthy neighborhoods became the core of the city's urban planning efforts, as in many other European cities (URBACT II, 2015).

To better understand the main drivers for the creation of BAM we first describe the development context of Porta Nouva, for it is within this vision that the park was created. The area has been a point of interest both for public and private real estate developers since the 1950s, as several aborted development plans tried to develop a business district in and around Isola (Brizioli et al., 2013). The breakthrough came when a partnership between the 
TABLE 3 | Baseline characteristics of BAM.

\begin{tabular}{ll}
\hline Baseline information & Biblioteca degli Alberi Milano \\
\hline Location & Milan, Italy, Porta Nuova district \\
Urban space or land use type & Public park \\
Function & Civic \\
Responsibility & Public-private \\
Development timeline & Design: 2004 Project: 2008-2018 \\
& Inauguration: 2018 \\
Dimensions & 95,000 m² (9.5 ha) \\
Budget & 14 million euros \\
Project Owner & Municipality of Milan \\
Developer and Management & From 2008-Municipality of Milan From \\
& $2015-$ COIMA SGR. \\
Designers & Petra Blaisse, Piet Oudolf, Studio \\
Industry certification/framework & Inside-Outside \\
\end{tabular}

American real estate developers Hines and the Italian investor Catella embraced the project in 1993. As a result, the area went under one of the largest mixed-use urban regeneration projects in Europe between 2005 and 2017, covering 300,000 square meters, with an investment totaling more than 2 billion EUR ${ }^{2}$ The project united three existing neighborhoods, -Garibaldi-Varesine-Isola-, to create a business-residential district with a focus on green technology and sustainable development, and is represented by two flagship projects; Bosco Verticale ${ }^{3}$ ("Vertical Forest" towers) by Stefano Boeri Studio and the Biblioteca degli Alberi ${ }^{4}$ park ("Library of Trees"), represented on Figure 2. The developments transformed the urban quality of the area architecturally and socially; the pedestrian areas were increased by $65 \%$, the cycling paths by $70 \%$ and the green areas by $40 \%$ in the entire neighborhood. The new area visually and culturally exemplifies the vision of an international, modern and creative city, in line with Milan's efforts to create a European smart city brand where eco-visons guide the city's development (Beretta, 2018). However, the transformation has been critiqued for a lack of concern of the surrounding, traditional Italian environment and ignoring the historic heritage of the site (Arcidiacono and Piga, 2008). Critical voices were raised against the modification of the urban skyline that changes the identity of Milan and leads to the "manhattanization" of the city, thereby giving the area a commercial appearance, reflecting only the vision of the private developers (Bergaglio, 2019, p 26).

\section{Biblioteca Degli Alberi; the Gardens of Porta Nuova}

The importance of the BAM comes from its central location in Porta Nuova and because it is one of the new urban parks that was developed to mitigate some of the city's environmental problems, such as heat, water run-off and lack of green space.

\footnotetext{
${ }^{2}$ http://www.porta-nuova.com/.

${ }^{3}$ https://www.stefanoboeriarchitetti.net/en/project/vertical-forest/

${ }^{4}$ https://www.insideoutside.nl/Biblioteca-degli-Alberi-Milan.
}

It is an innovative model of a public park entirely managed privately, with the flexibility of accommodating a range of different forms for public life. The "Library of Trees" concept was the winning entry of the "Porta Nuova Gardens International Design Competition" in the Integrated Intervention Program of the Municipality of Milan in 2004. A multidisciplinary team lead by Petra Blaisse's Inside Outside design studio from Amsterdam won the competition by addressing the recovery and functional redevelopment of the Garibaldi-Repubblica areas (development details are summarized in Table 3 and visualized in Figure 3). The design vision featured a "Library of Trees" concept, built on the traditions of botanical gardens and placed into a novel kind of park experience, one which allows tactile ways of understanding plants, herbs, and flowers in a city. The proposal presented the park as a strategic element linking the green area to the surrounding retail, fashion, and cultural infrastructure, to the offices and residential spaces. The mixed-use spatial structure thus facilitates channeling activity and interaction to the park, and the park's attraction helps to increase the economic spill-over around the area of Porta Nuova.

\section{The Outcomes: A Library of Trees, Shaped by Trees for Humans}

BAM is the third largest park of Milan. It hosts 500 trees in the shape of 22 circular forests, and 135,000 plants, including over 100 different species of shrubs, hedges, creepers, and climbing plants, aquatic and ornamental plants, aromatic plants, buds, and flowers (COIMA, 2018). The botanical richness of the park, with its flowery meadows ${ }^{5}$ and aromatic plants, contributes to the creation of an ecosystem in the city that favors the presence of pollinating insects. Some of the species are planted to provide feeding for birds and other city animals. BAM as an NBS has been featured in the Urban Nature Atlas ${ }^{6}$ developed by NATURVATION for its contribution to urban regeneration, green space development and provision of habitat for urban flora and fauna, thus ameliorating local biodiversity. These contributions are paired with co-benefits for the economic and labor market gained from increased tourism, retail and services traffic that the development has generated, along with sociocultural benefits attributed to the closeness of natural elements and the various programs inviting people in to participate.

From the interview narratives and the observation results, we assert how BAM's placemaking outcomes represent an integrated effort in urban design that can augment the relationships between individuals, communities, and urban space. Comfort and Image features can be traced from the high level of services, attractors, amenities that draw users in and encourage them to linger; to have an ice-cream or meal, lying on the ground and relax, to sunbathe, be with a group while enjoying the shades of the "treerooms." BAM's flowering meadows with views of Bosco Verticale have become a point of observation for a new, "manhattanized"

\footnotetext{
${ }^{5}$ Piet Oudolf's perennial gardens - author of the New York High Line, known for his wild-looking gardens- occupy almost 20,000 square meters in compositions enchanting visitors with spectacular alternating blooms of bright colors throughout the year.

${ }^{6} \mathrm{https} / / /$ naturvation.eu/atlas.
} 


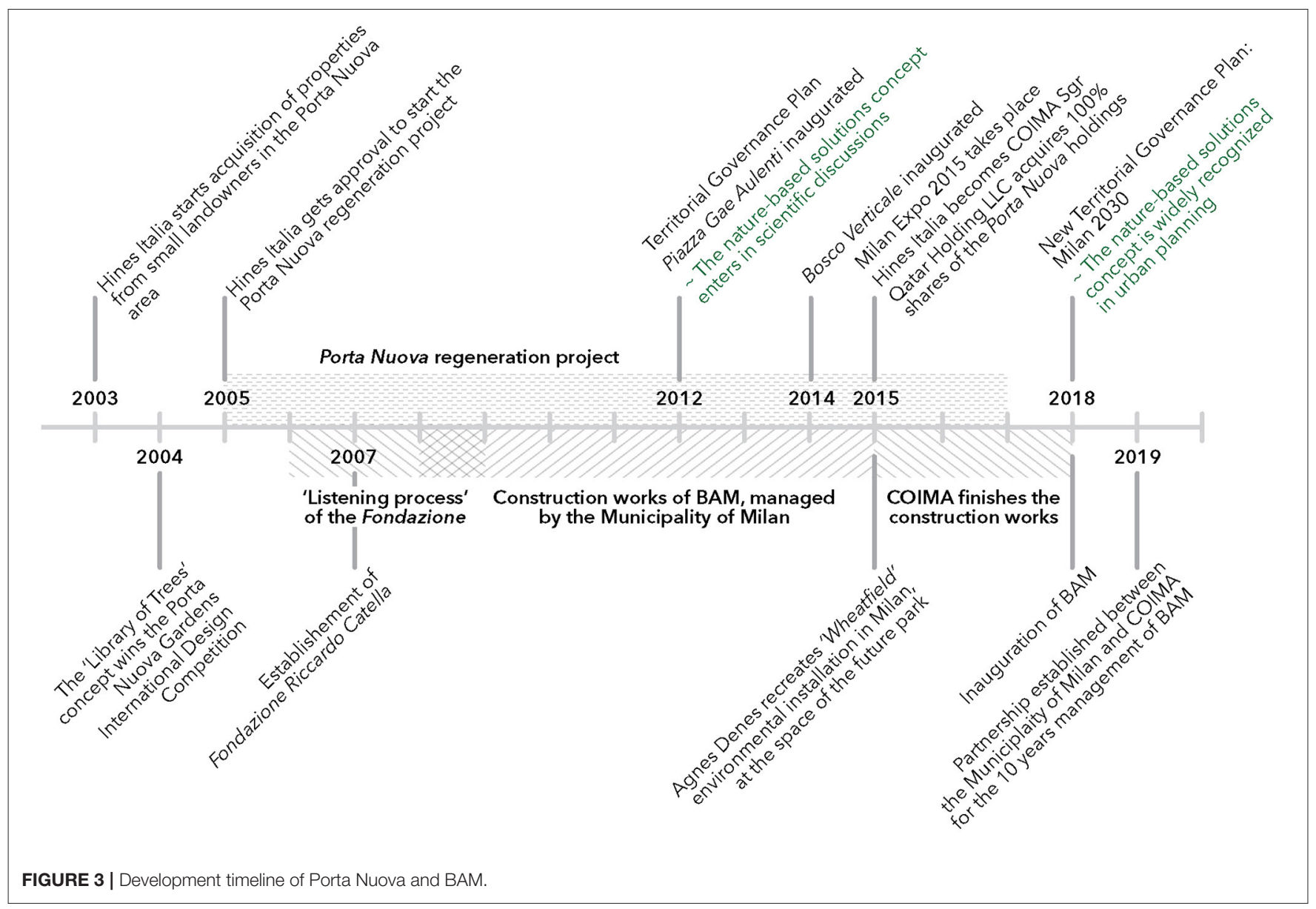

panorama of Porta Nuova, where green developments are mixed with shiny and chic high-rises. It became a must-see touristic destination, an embodied expression of a new city image. BAM is a Social space; gatherings of smaller and larger groups can be found even on rainy, cloudy days, and the park is busy with tourists. Diverse Uses and Activities can be observed; people doing sports like yoga, running or Thai-chi, street dance teams are practicing, families with kids are playing, businesspeople are having lunch or coffee, and groups of tourists are exploring the area by themselves or in organized guided tours. Typical park programs can be found: swings, playgrounds, outer gym, dog park, picnic, and relaxation areas together with vegetable gardens and aromatic fields with sage, thyme, rosemary, lavender, and mint, which offer opportunities for recreational-educational activities. There are water games, a bio pond, bocce fields, and lawn areas dedicated to cultural programs, markets, open-air art galleries, concerts, and conferences. The park is open $24 \mathrm{~h}$, and there is a considerable social activity during the night: teenagers gather at the swings, around the corners with cafés, or shops toward piazza Gae Aulenti, mixed with younger and less young adults enjoying the Milanese nightlife (Figure 4 shows "glimpses" of BAM's daily life). During the COVID-19 crisis, BAM also followed the pandemic restrictions in full lockdown. As life to public spaces reappeared now, some activities are also done in limited numbers and contained spaces, marked by circles designed on the ground to avoid people's gatherings in large numbers. In terms of Access and linkages, the area is truly a junction point. Three districts connect there, next to local and regional transport hubs. BAM has no gates or fences, only on a small part belonging to COIMA's foundation, the Fondazione Riccardo Catella's urban gardens (hereinafter Fondazione ${ }^{7}$ ). The park connects seamlessly to the nearby public spaces, thus creating the largest pedestrian area in the city with $170,000 \mathrm{sqm}$ of pedestrian and $5 \mathrm{~km}$ of bike paths (COIMA, 2018).

\section{The Design Process: Operationalizing Urban Space for NBS}

A multidisciplinary, professional team was involved in the design activities in a planned and top-down approach. The goals and requirements were given, and the means set by the project stakeholders, essentially, to reshape the identity and experience of the urban settings with extended urban greening. Project champions play a major role in maneuvering the various interests to bring about a successful implementation of designs, as described in both urban design (Carmona, 2014) and NBS research (IUCN, 2016). In the case of BAM, the interviewees have

$\overline{{ }^{7} \text { https://www.fondazionericcardocatella.org/en/. }}$ 


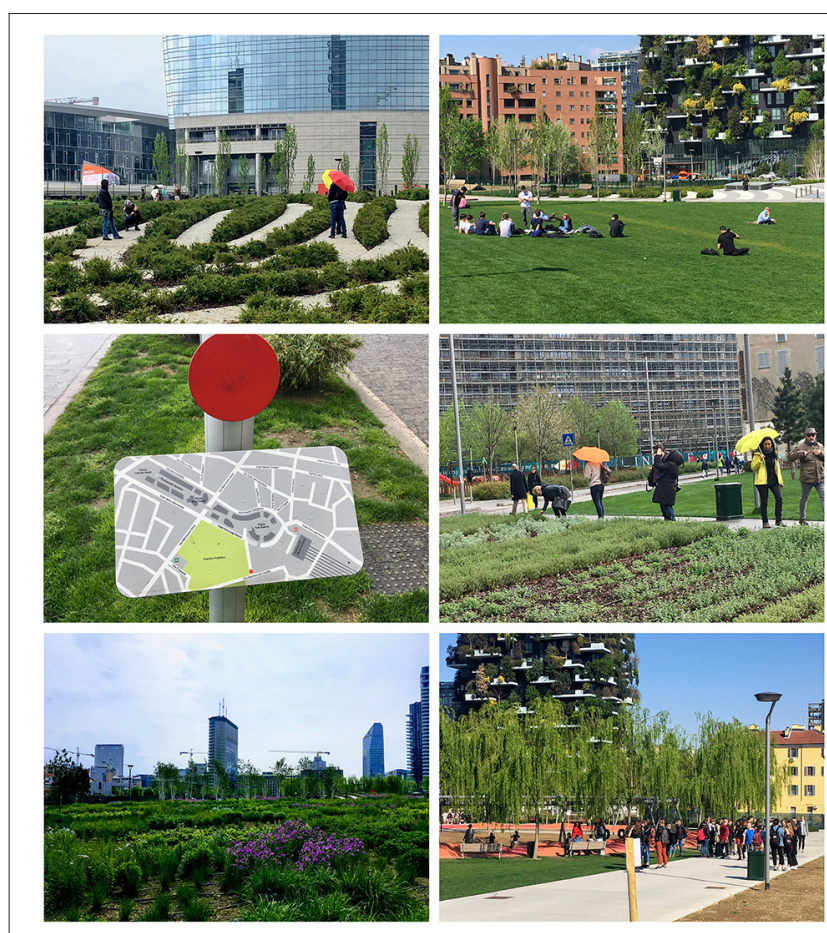

FIGURE 4 | From top left to right. People taking selfies from the photo spot where Bosco Verticale shows best in the background. People in groups relaxing on the grass. Wayfinding sign. Passers-by picking up herbs from the aromatic fields. Flowering meadow. Group of tourists visiting the area.

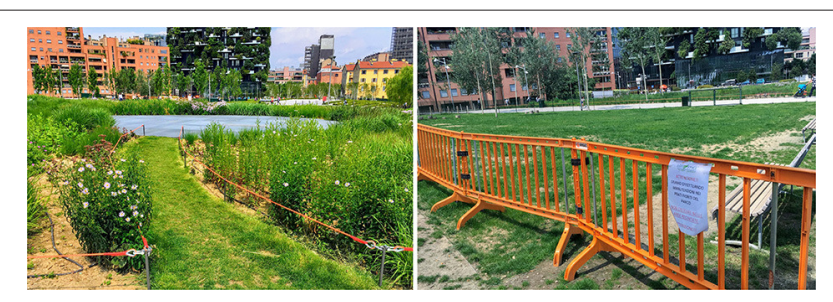

FIGURE 5 | Non-intrusive enclosure of areas that are restricted from use. Temporary closures are installed to help the vegetation to regrow.

reported that it was the Fondazione which has been playing a major part in the change of the area and in animating the space of BAM. The organization was established in 2007 to study and promote best practices in territorial development, to integrate art, activities, and public spaces. Currently, it manages community programs as part of COIMA's Porta Nuova Smart Community program. Between 2006 and 2009, they were using a "listening process," that is a series of meetings to learn about the daily life, needs and wishes of the neighborhood, and to inform and involve citizens in the planned urban interventions. Through the management of various civic and cultural programs, they contributed to the improvement of the area-even before the start of the regeneration project.

The Design phase is the first stage in the UDP framework, during which designers translate strategies defined for the public space to particular solutions to create the spaces for use. The project's timeline (see Figure 3) shows that after the acceptance of the design proposal in 2004, almost 10 years had passed until the project was finished. It took 4 years after the competition just to start the project and another 10 years to finish it. During those 4 years, a complete infrastructure was implanted underneath the park due to the new metro station development. Some sections had to be changed entirely, however, the original design concept was resilient enough to accommodate those changes because the design functioned more as a strategy. The vision of reconnecting the area into a social, cultural, and educational nexus was translated into the physical, geometric structure of the park through an interlacing system of paths. The idea was simple: the crisscrossing paths form intersections, each of which becomes a uniquely themed field, planted differently with specific function or role. The circular tree groupings reinforce the joints as the architectural yet the natural structure of the park. The result is a patchwork of flowering meadows, educational gardens, aromatic gardens, multi-functional lawns that can be easily changed or reconfigured.

Interestingly, the future park was already activated while being Developed. BAM's construction works were supposed to be ready by the opening of the Expo 2015 world fair, although severe delays held back the implementation. In the meantime, one of the newest attractions was the freshly opened "vertical forests" of Bosco Verticale, expected to attract many visitors and attention to BAM's unfinishedness. On the Fondazione's call, Agnes Denes, conceptual artist, was commissioned to recreate her iconic land artwork, "Wheatfield," within a 5-hectare space of the future park ${ }^{8}$. The art intervention was extensive in scale as well as in public participation. Through the Fondazione's MiColtivo ("Green Circle") initiative, the wheat was sowed, reaped, and harvested collectively with residents and visitors and tourists. After the Expo period, the MiColtivo initiative provided additional means to continue directly involving the citizens in the park's building phases, and to host cultural programs with concerts, and laboratories in the vegetable gardens, involving over 2,700 people (COIMA, 2018). On a technical construction level, the development of the park incorporated several sustainability measures ${ }^{9}$. The contaminated soil was rehabilitated, the local ash trees were saved and replanted after construction. The park's irrigation system uses greywater generated after the cooling or heating of the offices and residences in the area, stored in a large aquifer under the area. The park's footpaths and pavements are built with water-filtering concrete, with a draining capacity 100 times higher than conventional pavement. Rainwater is captured and returned to the soil, respecting the natural water cycle, and recharging the aquifer.

To characterize the Use phase of NBS, BAM has certain elements that favor the non-human, such as specific species of berries are planted designated for feeding the visiting birds, and the rich, flowering vegetation enhances biodiversity in the local flora and fauna. Nevertheless, the design is overly

\footnotetext{
${ }^{8}$ https://www.designboom.com/art/agnes-denes-wheatfield-fondazione-nicolatrussardi-07-15-2015/.

${ }^{9}$ https://bam.milano.it/the-park/pratiche-sostenibili/.
} 
human-centered, and the space could afford more from an ecological point-of-view. The Fondazione has been working to keep BAM busy ever since the opening: numerous programs and events are organized for a wide audience in all seasons. Group workout sessions themed as "Senior Fitness," "Dog Human Fitness," "Smart Gym for Workers," "Mom and Baby Yoga," and "Stroller Workout" are available weekly. There are open talks with philosophers, and writers regularly, and guided botanical walks to learn more about the design, architecture, and nature of the park. Free concerts, classical music, and piano performances are offered to the public, and even graduates of the Ballet School of the Accademia del Teatro alla Scala were dancing on the lawns. The events are realized through the Fondazione's collaborations and partnerships with several commercial actors. However, the park's excessive usage is paired with a high maintenance load and causes constant stress to the plantings due to the continual need to refresh some of the most used spaces. Consequently, the park always changes, and the design has to follow nature's pace of growth, while citizens need to learn how to comply with the customs and management of the park and how to share it in a way that everyone can appreciate its benefits. Temporary closures help the new seedlings to strengthen while some park functions are re-located or joined with other fields (Figure 5).

For a public park, BAM demands continuous and intensive Management and care with considerable security costs. A public-private partnership between the COIMA and the Municipality was established in 2019, according to which the Fondazione is responsible for the management, safety, surveillance, maintenance, and the operation of cultural programs for 10 years, with a focus on the involvement of residents (COIMA, 2019). The role of the programming is to provide sources for the financial sustainability for the park's care and management, which is significantly, $\sim 4$ times higher than of "regular" parks, as the interviews revealed. The benefits of the partnership are explicit on the Municipality's side, a dedicated public and private commitment toward a common goal that keeps the green heart of the regenerated area alive and healthy. The interests of COIMA are similar: BAM is an investment and the experiences gained serve to refine COIMA's development model to be replicated in other development sites. Furthermore, an additional 3,500 sqm of "Events spaces" will be attached to BAM, outside the park, in the pedestrian area. In exchange for an annual fee, sponsors will be able to use the spaces for social, sports-oriented, and cultural events. With this extension, COIMA projects decreasing the green areas' overuse and expanding the park's maintenance funds (ibid).

\section{DISCUSSIONS: IMPLICATIONS OF URBAN DESIGN IN THE APPLICATION AND PERFORMANCE OF NBS}

When looking at the whole design process of BAM, it is revealed that the design capacity for developing well-functioning NBS requires more than eco-efficiency and needs measures that spread over the entire project timeline and all domains. In the case of BAM this includes sustainable construction and development led by COIMA, community building practices managed by the Fondazione and the urban design and landscaping strategy created by Inside-Outside, among other things. A "design for nature-based solutions" approach has emerged, making the process more deliberate, even if the concept of NBS enters only at a later stage for it provides a decision arena where issues and concerns can be targeted to align the many divergent interests of market and bureaucracy toward a transformation for maintaining urban sustainability.

The research showed how design affects all stages of NBS implementation. Moreover, design issues do not finish once the project is completed. A key part of activities involving design kicks off after a place opens, by setting conditions for changes in the natural or built environment. However, the proactive impact of design professionals generally stops at the "design" phase, as confirmed by interviewees, simply because the contracts do not cover ongoing involvement for the later stages after the design plans have been delivered. The Fondazione's dedication and care have bridged the usual problem of short-termed thinking and planning. Since they have been part of the process from the beginning, they could ensure that the original design conceptand the nature-based qualities- keep their integrity throughout the developments and later.

Coincidentally, the configurative aspect of urban design can advance the conceptualization and use of NBS elements in all UDP stages; to reach for the highest ecological potential and tackle uncertainties related to their application in development plans. Long development periods are not uncommon in the domain of urban development: 5-10 years can pass from the concept phase to inauguration (Hes et al., 2020). Yet keeping the relevance and validity of the design vision poses significant challenges for they have to accommodate both present and future requirements. Adaptability and flexibility are equally important notions in terms of capabilities of NBS enhancing the resilience of space (Bush and Doyon, 2019) when there are possibilities for alternative uses, reversibility of decisions, and adjustable implementation (Mcphearson et al., 2014; Cohen-shacham et al., 2019; Dorst et al., 2019). The functional and adaptable design system seems to be one of the park's critical components. It provides flexibility in the application of park elements and themes, and therefore responsiveness to managing the everchanging needs arising from the park's uses. Resilient urban design gives space for adopting "learning by doing" principles and involving transdisciplinary co-design approaches, ultimately dealing with uncertainties inherent in social-ecological systems (Ahern et al., 2014). BAM shows such features throughout its UDP framework, with a dynamic and flexible approach that is cardinal for integrating resilience thinking into urban design (Sharifi and Yamagata, 2018).

A design framework which facilitates community engagement and involvement is critically important for lively and sustainable public spaces (Schlebusch, 2015), and BAM's design qualities do prioritize this principle at all stages of the UDP. Moreover, residents and non-residents have been playing an important role in the planning and management of BAM, nonetheless, not through a tightly managed participatory design process, but through curated events and programming. The large 
variety of available services, programming, and branding are all tools (Lew, 2017) that characterize BAM's ongoing topdown placemaking and are also key factors in creating tourism destinations (Richards, 2017), which is further enhanced by the always-open-no-fence approach and direct pedestrian connection with neighboring streets and piazzas. BAM's NBS narrative makes the benefits explicit, utilizing the newly implemented natural resources, further enforced by reputations on social media, general news, and PR activities.

Extended use of placemaking activities are connected to a major part of BAM's UDP framework, illustrating how artbased or "creative placemaking" can put urban planning and community building in a different perspective, while stimulating local economies (Markusen and Nicodemus, 2014). Furthermore, the case of BAM shows how creative placemaking can help to identify and evaluate sources of flexibility. Agnes Denes' artwork was used to overcome development setbacks, while opening an opportunity to involve and inform citizens, to engage with local history, questions of ecological quality, and the appreciation of natural resources. The literature on placemaking often features bottom-up community-building efforts, but placemaking can also complement top-down economic agendas (Coghlan et al., 2016). The use of events in place marketing illustrates this claim: events can not only be used for marketing but also for generating a collaborative dialogue to broaden the event's role in shaping the sense of place. Denes' installation was the first event to "hallmark" the place (Ashworth, 2009), a process that over time transformed it from the Library of Trees into a professionally branded ${ }^{10}$ entity. One of the results of the coordinated approaches to development, promotion and management of the place is that BAM gained broader recognition in local and wider networks, building a distinctive identity by utilizing the "nature-basedness" of the park. In the case of BAM, associations with the park being a nature-based solution are firmly linked to city marketing and place branding strategies, but they also work the other way, to recognize the importance of designated places for NBS within major urban developments.

The UDP framework reviewed in this paper sheds light on two sides of the same coin: how urban design contributes to shaping NBS in an urban context, and how NBS enhance the outcomes of urban design, reconciling development interests with socioecological applications and expectations. At the practical level, the design of spaces is critical in affecting the quantity and quality of interpersonal and even interspecies experiences, interactions, and perceptions. Ideally, carefully planned NBS allow citizens to experience the many aspects of its benefits and enables them to perceive urban space, its functions, and potentials differently. BAM' sensory gardens, community gardens, visually engaging flower meadows allow for certain meaning-making and engagement with non-human urban ecosystem elements, even though the approach and results are still primarily human-centered. A human and socially centered approach is unquestionably important for improving the urban fabric, but for placemaking with NBS it is particularly important that the

\footnotetext{
${ }^{10} \mathrm{https} / / / \mathrm{www}$. interbrand.com/newsroom/interbrand-creates-brand-identitybam-milans-newest-park/
}

design caters to the human and non-human natural environment alike without undermining the role of nature in the interest of meeting well-being and liveability objectives (Hes et al., 2020). BAM has some elements dedicated to the non-human, but it has been affirmed by interviewees that its ecological impacts could be further scaled up via rewilding actions or by measures to further increase its biodiversity.

The predominantly human-centered design approach of BAM stems also from the fact that BAM is an old concept, conceived 15 years ago. In 2004 when the design idea was presented, discussions around "solutions using nature" were not in the mainstream. However, by the time the park opened in 2018, the concept of NBS was already part of the science, policy and social discourse (Eggermont et al., 2015; IUCN, 2016; Potschin et al., 2016; Nesshöver et al., 2017), widely recognized in the world of urban planning for delivering multiple benefits, including their contribution to reducing climate risk (Frantzeskaki, 2019). By 2018, communication about BAM presented the park as an NBS, putting explicit emphasis on the use of nature as a response to some of the city's major challenges such as mitigating the effects of climate change and air pollution. Utilizing the NBS narrative could be contested as only a justification for the (privately managed public) project, however, BAM demonstrates the functioning of a real-life NBS; achieving to reach environmental, social, and economic impacts by harnessing the power of urban nature. This historic view underlines that an urban ecology perspective is highly needed in the entirety of the design process for a successful re-scoping of urban design practices to place ecology, and the non-human to the forefront of design and planning activities, and ultimately to infuse human-centeredness with nature-basedness. It is important to note, that BAM's story is ongoing. Its current management arrangement shows how the last decades' reforms related to the city's strategic planning are bearing fruit and brought spatial planning and economic development strategies closer (Fontanari et al., 2017).

Applying the UDP framework to study the development of NBS proved to be a valuable tool for re-evaluation, learning, and identifying areas of success and of potential improvements, and possibly can be used at any stage of the development process. Coupled with an evaluation of placemaking processes in an ex-post analysis can support ongoing development, foster learning, and reflection, and provide more transparency about the evolution of urban spaces. This perspective, however, depends on specific design and governance practices that can differ in various cultures. Moreover, to gain an overarching view is highly challenging, since such a process is not a clear, linear, repeating series of stages in time nor is independent of the social, economic, and political context. Further context-specific research is needed to understand wholly the effects of design on NBS and its transformative potential in cities.

The paper shows that the creation of BAM, as a highly functioning NBS is not only the intentional effect of institutional strategies, public policies, or market-driven ambitions but marked by multiple creative and cultural practices driven by design. For activating NBS, then, a strategic design framework, 
applied to the entire design process, is needed that embraces future-oriented solutions-while being firmly grounded in place-and a continuous, flexible learning trajectory, that can react to changes in an adaptive manner with space for trials and experiments. To conclude, the research shows that embedding NBS in mainstream urban development processes can transform a market-driven development process into an inclusive socioeconomic, even positive development, as Birkeland (2012) defined it. It also shows how a "design-for-NBS" approach can make its way into mainstream planning practices, addressing varied interests and user groups through professional and engaging solutions.

\section{DATA AVAILABILITY STATEMENT}

The raw data supporting the conclusions of this article will be made available by the authors, without undue reservation.

\section{ETHICS STATEMENT}

The studies involving human participants were reviewed and approved by Ethical Research Committee of the

\section{REFERENCES}

Ahern, J., Cilliers, S., and Niemelä, J. (2014). The concept of ecosystem services in adaptive urban planning and design: a framework for supporting innovation. Landsc. Urban Plan. 125, 254-259. doi: 10.1016/j.landurbplan.2014.01.020

Arcidiacono, A., and Piga, B. E. A. (2008). Il caso di Garibaldi- Repubblica: Simulazioni spaziali e valutazione dell'impatto cumulato dei progetti urbani. Territorio, 43, 40-52.

Ashworth, G. J. (2009). The instruments of place branding: how is it done? Eur. Spat. Res. Policy 16, 9-22. doi: 10.2478/v10105-009-0001-9

Bayulken, B., and Huisingh, D. (2015). A literature review of historical trends and emerging theoretical approaches for developing sustainable cities (part 1). J. Clean. Prod. 109, 11-24. doi: 10.1016/j.jclepro.2014.12.100

Beretta, I. (2018). The social effects of eco-innovations in Italian smart cities. Cities 72, 115-121. doi: 10.1016/j.cities.2017.07.010

Bergaglio, M. (2019). Inhabit Utopia : a new outcome for large regenerated industrial areas in Milan. Altre Modernità, September 14-31.

Birkeland, J. (2012). Positive Development From Vicious Circles to Virtuous Cycles Through Built Environment Design. London: Routledge.

Brink, E., Aalders, T., Ádám, D., Feller, R., Henselek, Y., Hoffmann, A., et al. (2016). Cascades of green: a review of ecosystem-based adaptation in urban areas. Global Environ. Change 36, 111-123. doi: 10.1016/j.gloenvcha.2015.11.003

Brizioli, A., Caffoni, P., Figone, C., Piccolo, S., Schiltz, M., and Theis, B. (2013). Fight-specific Isola: Arte, architettura, attivismo e il futuro della città. Berlin: Archive Books.

Buijs, A., Hansen, R., Jagt, S., Van, D.er, Ambrose-oji, B., Elands, B., Lorance, E., et al. (2019). Mosaic governance for urban green infrastructure: upscaling active citizenship from a local government perspective. Urban For. Urban Green. 40, 53-62. doi: 10.1016/j.ufug.2018.06.011

Bulkeley, H., Bracken, L., Almassy, D., Pinter, L., Naumann, S., Davis, M., et al. (2017). NATURVATION: State of the Art Review: Approach and Analytical Framework.

Bush, J., and Doyon, A. (2019). Building urban resilience with naturebased solutions : How can urban planning contribute? Cities. 95, 102483. doi: 10.1016/j.cities.2019.102483
Central European University. The patients/participants provided their written informed consent to participate in this study.

\section{AUTHOR CONTRIBUTIONS}

JB and IM both contributed in the design and writing of the manuscript. Both authors contributed to the article and approved the submitted version.

\section{FUNDING}

This research received funding from Central European University Foundation, Budapest, and from NATURVATION, a European Union's Horizon 2020 research and innovation program under grant agreement No. 730243.

\section{ACKNOWLEDGMENTS}

The authors wish to express sincere acknowledgments to Dr. Alexander van der Jagt, Prof. László Pintér, Prof. Katalin Szende, and Prof. Eugenio Morello for their valuable suggestions in completing this article.

CABE, University College London, and DETR (2001). The Value of Urban Design: A Research Project Commissioned by CABE and DETR to Examine the Value Added by Good Urban Design. London: ThomasTelford.

Carmona, M. (2010). Contemporary public space: critique and classification, part one: critique. J. Urban Des. 15, 123-148. doi: 10.1080/13574800903435651

Carmona, M. (2014). The place-shaping continuum : a theory of urban design process. J. Urban Des. 19, 2-36. doi: 10.1080/13574809.2013.854695

Carmona, M. (2019). Place value: place quality and its impact on health, social, economic and environmental outcomes. J. Urban Des. 4809, 1-48. doi: 10.1080/13574809.2018.1472523

Ceschin, F., and Gaziulusoy, I. (2016). Evolution of design for sustainability: from product design to design for system innovations and transitions. Des. Stud. 47, 118-163. doi: 10.1016/j.destud.2016.09.002

Coffey, B., Bush, J., Mumaw, L., de Kleyn, L., Casey, F., Cretney, R., et al. (2020). Towards good governance of urban greening : insights from four initiatives in Melbourne, Australia. Aust. Geogr. 51, 189-204. doi: 10.1080/00049182.2019.1708552

Coghlan, A., Sparks, B., Liu, W., and Winlaw, M. (2016). Reconnecting with place through events in the placemaking agenda. Int. J. Event Festiv. Manag. 8, 66-83. doi: 10.1108/IJEFM-06-2016-0042

Cohen, M., Gajendran, T., Lloyd, J., Maund, K., Smith, C., Bhim, S., et al. (2018). Valuing Creative Placemaking: Development of a Toolkit for Public and Private Stakeholders. Sydney, Australia. Available online at: https://nova.newcastle.edu. $\mathrm{au} / \mathrm{vital} /$ access/manager/Repository/uon:32653 (accessed date May 17, 2021).

Cohen-shacham, E., Andrade, A., Dalton, J., Dudley, N., Jones, M., Kumar, C., et al. (2019). Core principles for successfully implementing and upscaling Nature-based Solutions. Environ. Sci. Policy 98, 20-29. doi: 10.1016/j.envsci.2019.04.014

COIMA (2018). Press Realease: Milan's Newest Public Park, the Third Largest in the City's Center Opens Its Doors to the Public. Available online at: http:// hub.coima.com/wp-content/uploads/2018/10/PR_COIMA_Biblioteca-degliAlberi_27_10_2018_EN.pdf (accessed December 06, 2019).

COIMA (2019). Press Realease: The Management of the Park Biblioteca Degli Alberi Has Been Awarded to COIMA-Through Fondazione Riccardo Catella. Available online at: https://www.coima.com/en/media/press-releases/the- 
management-of-the-park-biblioteca-degli-alberi-has-been-awarded-tocoima-through-fondazione-riccardo-catella (accessed December 06, 2019).

Connop, S., Vandergert, P., Eisenberg, B., Collier, M. J., Nash, C., Clough, J., et al. (2015). Renaturing cities using a regionally-focused biodiversity-led multifunctional benefits approach to urban green infrastructure. Environ. Sci. Policy 62, 99-111. doi: 10.1016/j.envsci.2016.01.013

Dorst, H., Jagt, A., Van, D.er, Raven, R., and Runhaar, H. (2019). Urban greening through nature-based solutions - key characteristics of an emerging concept. Sustain. Cities Soc. 49:101620. doi: 10.1016/j.scs.2019. 101620

Eggermont, H., Balian, E., Azevedo, J. M. N., Beumer, V., Brodin, T., Claudet, J., et al. (2015). Nature-based Solutions: new influence for environmental management and research in Europe. GAIA 24, 243-248. doi: 10.14512 /gaia.24.4.9

European Commission (2015). Towards an EU Research and Innovation Policy Agenda for Nature-Based Solutions and Re-Naturing Cities.

European Environment Agency (2019). Europe's Urban Air Quality - ReAssessing Implementation Challenges in Cities. Available online at: https://www. eea.europa.eu/publications/europes-urban-air-quality (accessed date May 17, 2021).

Fincher, R., Pardy, M., and Shaw, K. (2016). Place-making or place-masking? The everyday political economy of “making place." Plan. Theory Pract. 9357, 1-21. doi: 10.1080/14649357.2016.1217344

Fontanari, E., Wacogne, R., and Perez, J. R. (2017). PICH: the impact of urban planning and governance reform on the historic built environment and intangible cultural heritage.

Foot, J. (2001). Milan Since the Miracle: City, Culture and Identity. Oxford: Berg Pub Limited. doi: 10.5040/9781350151444

Frantzeskaki, N. (2019). Seven lessons for planning nature-based solutions in cities. Environ. Sci. Policy 93, 101-111. doi: 10.1016/j.envsci.2018. 12.033

Galbraith, R. (2007). An urban renaissance is transforming Milan: Yielding to a service economy, city remakes itself as the largest construction site in Europe. Herald International Tribute. Available online at: https://adhoccommunication. it/wp-content/uploads/2015/03/HINES-2.pdf (accessed date May 17, 2021).

Gehl, J., and Svarre, B. (2013). How to Study Public Life. Washington DC: Island Press. doi: 10.5822/978-1-61091-525-0

Gulsrud, N. M., Hertzog, K., and Shears, I. (2018). Innovative urban forestry governance in Melbourne: investigating "green placemaking" as a nature-based solution. Environ. Res. 161, 158-167. doi: 10.1016/j.envres.2017.11.005

Hansen, R., Stahl Olafsson, A., van der Jagt, A., Rall, E., and Pauleit, S. (2019). Planning multifunctional green infrastructure for compact cities: what is the state of practice? Ecol. Indic. 96, 99-110. doi: 10.1016/j.ecolind.2017.09.042

Hes, D., Hernandez-Santin, C., Beer, T., and Huang, S.-W. (2020). "Place evaluation: measuring what matters by prioritising relationships," in Placemaking Fundamentals for the Built Environment, eds D. Hes, and C. Hernandez-Santin (Singapore: Palgrave Macmillan), 275-303. doi: 10.1007/978-981-32-9624-4_13

International Union for Conservation of Nature (IUCN) (2016). Nature-Based Solutions to Address Global Societal Challenges. Gland: International Union for Conservation of Nature.

ISTAT (2010). Air Quality in European Cities 2004-2008, 2005, 1-5. Available online at: https://www.istat.it/en/files/2011/01/qualita_aria_EN.pdf?title= Air $\$+\$$ quality $\$+\$$ in $\$+\$$ European $\$+\$$ cities $\$+\$-\$ 22 \$+\$$ Jun $\$+\$ 2010 \$+\$-\$$ \$qualita_aria_EN.pdf (accessed date May 17, 2021).

Kabisch, N., Stadler, J., Korn, H., and Bonn, A. (2016). Nature-Based Solutions to Climate Change Mitigation and Adaptation in Urban Areas. Cham: Springer. doi: 10.1007/978-3-319-56091-5

Lew, A. A. (2017). Tourism planning and place making: place-making or placemaking? Tour. Geogr. 19, 448-466. doi: 10.1080/14616688.2017.1282007

Mahmoud, I., Morello, E. (2020). Are Nature-based solutions the answer to urban sustainability dilemma? The case of CLEVER Cities CALs within the Milanese urban context. In: Atti della XXII Conferenza Nazionale SIU. L'Urbanistica italiana di fronte all 92Agenda 2030. Portare territori e comunitá sulla strada della sostenibilit0 e della resilienza. SIU Societ0 Italiana degli Urbanisti, Bari Matera, pp 1322-1327.
Mahmoud, I., and Morello, E. (2021). "Co-creation pathway for urban nature-based solutions: testing a shared-governance approach in three cities and nine action labs," in Smart and Sustainable Planning for Cities and Regions, Green Energy and Technology, eds A. Bisello, D. Vettorato, D. Ludlow, and C. Baranzelli (Cham: Springer International Publishing), 259-276. doi: 10.1007/978-3-030-577 64-3_17

Markusen, A., and Nicodemus, A. G. (2014). Creative placemaking: how to do it well. Commun. Dev. Invest. Rev. 2, 35-42. http://www.petkovstudio.com/bg/ wp-content/uploads/2017/03/creative-placemaking-how-to-do-it-well.pdf

McCormick, K., Anderberg, S., Coenen, L., and Neij, L. (2013). Advancing sustainable urban transformation. J. Clean. Prod. 50, 1-11. doi: 10.1016/j.jclepro.2013.01.003

Mcphearson, T., Andersson, E., Elmqvist, T., and Frantzeskaki, N. (2014). Resilience of and through urban ecosystem services. Ecosyst. Serv. 12, 152-156. doi: 10.1016/j.ecoser.2014.07.012

Mell, I. C., Henneberry, J., Hehl-Lange, S., and Keskin, B. (2013). Promoting urban greening: valuing the development of green infrastructure investments in the urban core of Manchester, UK. Urban For. Urban Green. 12, 296-306. doi: 10.1016/j.ufug.2013. 04.006

Nesshöver, C., Assmuth, T., Irvine, K. N., Rusch, G. M., Waylen, K. A., Delbaere, B., et al. (2017). The science, policy and practice of nature-based solutions: an interdisciplinary perspective. Sci. Total Environ. 579, 1215-1227. doi: 10.1016/j.scitotenv.2016.11.106

Nouri, A. S., and Costa, J. P. (2017). Placemaking and climate change adaptation: new qualitative and quantitative considerations for the "Place Diagram”. J. Urban. Int. Res. Placemaking Urban Sustain. 10, 356-382. doi: 10.1080/17549175.2017.1295096

Palazzo, D., and Steiner, F. (2011). Urban Ecological Design: A Process for Regenarative Places. Oxford: Island Press. doi: 10.5822/978-1-610 91-226-6

Potschin, M., Kretsch, C., Haines-Young, R., Furman, E., Berry, P., and Baro, F. (2016). "Nature-Based Solutions," in OpenNESS Ecosystem Services Reference Book, eds. M. Potschin, and K. Jax (EC FP7 Grant Agreement no. 308428). Available online at: www.openness-project.eu/library/reference-book. (accessed date May 17, 2021).

Project for Public Spaces (2016). Research: The Case for Healthy Places. Available online at: https://www.pps.org/article/pps-releases-new-report-the-case-forhealthy-places-how-to-improve-health-through-placemaking (accessed date May 17, 2021).

Raymond, C. M., Berry, P., Breil, M., Nita, M. R., Kabisch, N., de Bel, M., et al. (2017). An Impact Evaluation Framework to Support Planning and Evaluation of Nature-based Solutions Projects. Report prepared by the EKLIPSE Expert Working Group on Nature-based Solutions to Promote Climate Resilience in Urban Areas. Wallingford, United Kingdom.

Richards, G. (2017). From place branding to placemaking: the role of events. Int. J. Event Festiv. Manag. 8, 8-23. doi: 10.1108/IJEFM-09-2016-0063

Schlebusch, S. (2015). Planning for sustainable communities: evaluating place-making approaches. Agric. For. Fish. 4, 59-72. doi: 10.11648/j.aff.s.2015040401.18

Sharifi, A., and Yamagata, Y. (2018). "Resilience-oriented urban planning," in Resilience-Oriented Urban Planning, eds A. Sharifi, and Y. Yamagata (Cham: Springer), 3-27. doi: 10.1007/978-3-319-75 798-8_1

URBACT II (2015). Sustainable regeneration in urban areas.

van der Jagt, A. P., Raven, R., Dorst, H., and Runhaar, H. (2020). Naturebased innovation systems. Environ. Innov. Societal Transitions, 35, 202-216. doi: 10.1016/j.eist.2019.09.005

Wyckoff, M. A. (2014). Definition of Placemaking: Four Different Types. Plan. Zoning News 32:1. http://www.pznews.net/media/ 13f25a9fff4cf18ffff8419ffaf2815.pdf

Xiang, P., Wang, Y., and Deng, Q. (2017). Inclusive nature-based solutions for urban regeneration in a natural disaster vulnerability context: a case study of Chongqing, China. Sustainability 9:1205. doi: 10.3390/su9 071205 
Yin, R. K. (2017). Case Study Research and Applications: Design and Methods. New York, NY: Sage Publications.

Conflict of Interest: The authors declare that the research was conducted in the absence of any commercial or financial relationships that could be construed as a potential conflict of interest.
Copyright $\odot 2021$ Boros and Mahmoud. This is an open-access article distributed under the terms of the Creative Commons Attribution License (CC BY). The use, distribution or reproduction in other forums is permitted, provided the original author(s) and the copyright owner(s) are credited and that the original publication in this journal is cited, in accordance with accepted academic practice. No use, distribution or reproduction is permitted which does not comply with these terms. 